\title{
Culture, identity and alternatives to the consumer culture
}

\section{Cultura, identidade e alternativas à cultura do consumidor}

\author{
Carolyn M. Kagan ${ }^{1}$ \\ Mark H. Burton²
}

\begin{abstract}
This article explores questions of identity and culture in relation to the present systemic crises that confront human life on the planet, problematizing the pursuit of economic growth and consumerist culture. It uses the concept of Ideology-Action-Structure complexes to understand the saturating nature of social, political and economic domination, and then explores interventions in these complexes, which all have characteristics of informal education, to promote cultural growth, create new settings and establish a counter-hegemonic ideology and alliance. It is suggested that by joining up fragmented local interventions and movements, there is hope that society's way of life can be shifted to one where cultural enrichment supports a less resource-exploitative economic and cultural model.
\end{abstract}

Keywords: culture; consumerism; economy; ideology-action-structure complexes; crises.

\section{RESUMO}

Este artigo explora questões da identidade e cultura no tocante às atuais crises sistemáticas que desafiam a vida humana neste planeta. Problematiza-se a intensa busca pelo crescimento econômico e cultura do consumo. Utiliza-se o conceito de complexos da Ideologia-Ação-Estrutura para entender a natureza de caráter saturante da dominação social, política e econômica.

DOI: $10.1590 / 0104-4060.36583$

1 Manchester Metropolitan University. Manchester, United Kingdom. Elizabeth Gaskell Campus. Hathersage Road, M13 0JA.

2 Manchester Metropolitan University. Manchester, United Kingdom. Geoffrey Manton Building Rosamond Street West off Oxford Road, M15 6LL. 
Assim, exploram-se as intervenções nestes complexos, que assumem características da educação informal para promover o crescimento cultural, criando cenários novos que objetivam estabelecer uma ideologia e aliança contra-hegemônica. Sugere-se que, ao se conseguir unir intervenções e movimentos ainda fragmentados e localizados, pode existir a esperança que poderia transformar o modo de vida da sociedade para as pessoas em que o enriquecimento cultural apoiaria um modelo econômico e cultural que explorasse menos os recursos ambientais.

Palavras-chave: cultura; consumismo; economia; complexo de ideologia-ação-estrutura; crise.

\section{Introduction: $21^{\text {st }}$ century malaise}

In this article we will explore some questions about culture and identity in relation to the present systemic crises that threaten not just the social and economic well-being of human beings throughout the world, but also threaten the very basis for human life on earth. In approaching these big questions we will focus on some of our own work, drawing lessons for cultural education and conscientization in relation to alternative social models.

We begin by painting a picture of what we term " $21^{\text {st }}$ Century malaise". A series of linked crises, or gathering storms, are afflicting societies across the world. They can be described in a variety of ways, and we suggest the following:

An ecological crisis, with climate change and other planetary boundaries being crossed (ANDERSON; BOWS, 2008; ROCKSTRÖM et al., 2009), is likely to lead to the collapse of the support systems for human life. As people's habitats are squeezed we can expect to see more conflicts of the most basic kinds - competition for resources to sustain life (MARTINEZ-ALIER, 2009; MEADOWS, D. H.; RANDERS; MEADOWS, D. L., 2005).

An energy crisis, with peak oil leading to rapid escalation of energy costs with profound consequences for the economy, agriculture, supply chains, etc. As we are no longer able to live our energy-rich lives we will see profound changes in the ways in which people live together, construct communities and organise work, family and leisure lives (HEINBERG, 2004). Alternatively, since the bulk of hydrocarbon fuels must be left unexploited to avoid runaway global warming there is likely to be a severe energy crisis irrespective of the total size of the remaining reserves which become a speculative bubble themselves, since the stocks are overvalued. 
A demographic crisis, with worldwide population growth and, in many parts of the world, ageing populations, but in others there are missing middle generations; population movements and displacements due to climate shocks, war, economic shocks and neoliberal strategies. As hitherto stable patterns of populations change rapidly, existing social relations will be put under pressure with the dangers of increased violence and exploitation (DAVIS, 2007; UNITED NATIONS POPULATION FUND, 2013).

An economic crisis, comprising a structural crisis of Capital and the undoing of the most recent strategies to maintain accumulation while accentuating strategies that attack living standards, previous gains, ecosystems, livelihoods (AFOKO; VOCKINS, 2013; HARVEY, 2010). Governments' pursuit of unselective, aggregate economic growth will serve to deepen the crisis (VICTOR, 2008, 2011).

A social and cultural crisis, in which the human and cultural capital of our societies is eroded and the humanising practices of social solidarity and cultural production are displaced by a model of passivity-inducing consumerism (ASSADOURIAN, 2010; JAMES, 2008; LATOUCHE, 2012b; WILLIAMS, 2006), fuelled by the enormous expansion of consumer credit and household debt, itself feeding the secondary, speculative, global finance sector whose speculative bubbles triggered the 2008 global crash (HARVEY, 2010).

These crises share the following characteristics: they

a) are interdependent; and

b) have a systemic nature (not easily described, not easily predicted, complex and with properties that emerge. They are non-linear, having positive ('vicious') feedback loops and quasi-autonomous subsystems;

c) differentially affect the poor, women, disabled people, the elderly, children, the working class and those reliant on the informal economy, peasants and members of minority or dominated ethnic groups;

d) are likely to lead to a succession of waves of misery, conflict, population movement, hunger and want. Much of this 'future' is here already;

e) their nature is not transparent, partly because of the complexity of global systems and partly due to the result of obfuscation through ideology and propaganda;

f) Finally, they present us with perhaps our greatest challenge as educators and social psychologists, to understand the contribution we can make, and not to get disheartened by the scale of the problems. Will it be enough to continue to "think globally but act locally" (a mantra often repeated by community psychologists), or will we need to consider how we up-scale our actions and our learning, and join up the fragments?

To provide some theoretical support for this analysis, we have been using a framework (BURTON, 2013a, p. 803-804) of Ideology-Action-Structure Com- 
plexes (IASCs) in which ideology, action and structure support each other. These ideology-action-structure complexes can be clustered in terms of capitalism (the system whose central purpose is the accumulation of capital), imperialism/ colonisation (the domination and exploitation of large regions of the world by a succession of nation states and clusters of states), modernity (the adoption of a rationalistic order in society characterised by a set of divisions: between arts and science, economy, law and humanities, ritual and production, humans and nature) and naturalism (in which socially constructed divisions and distinctions are taken to be part of the natural order of things). Burton identified seven of these (see Figure 1).

a) The rational administration of complexity.

This is the administrative impulse to order and simplify rather than describing the dimensions and layers of complexity, working with the flow. By reducing complexity to a few elements, controlling them, the hope is to manage the complex system itself.

b) Taming natures.

The wild, the natural, is to be controlled, to be mastered, enclosed and channelled, or suppressed. It is seen as or turned into resources. It is seen as separate from humanity, and humanity as separate from it. When valued it is appreciated in a distorted version of itself.

c) Linear progress.

Progress is a culturally located idea, absent in some languages. It implies a linear path from the primitive to the modern, with no detours and no end. It is authoritarian since it defines other paths 'out of scope'. After all, 'you can't stand in the way of progress'.

d) The dominance of exchange and possession.

As Marx and Engels said, 'All that is solid melts into air...' ...or rather money. What was once free is subject to exchange relations. That which was once common is now owned. All that is intangible is made concrete, possessed, processed and sold. However, the domination of exchange and possession predates capitalism, suggesting a more fundamental dynamic (GROSFOGUEL, 2008).

e) The primacy of exploitation.

The system depends on exploitation. The high levels of consumption of the few (globally) depend on labour exploitation of varying degrees of savagery and on the ruthless exploitation of the planet's living and mineral resources (LANDER, 2010; WOODWARD et al., 2006).

f) Mono-culturality and the suppression of other cultural systems.

Particular cultural forms dominate where culture means the ordinary ways we live, and pass on and share that way of life through traditions, 
crafts, arts, rituals and the material trappings of everyday life. Alien cultures are variously suppressed, trivialised or co-opted. And we are now faced with ever greater homogenisation just as identity politics is celebrated. By "culture" we mean the way we live, and pass on and share that way of life through traditions, crafts, arts, rituals and the material trappings of everyday life. As the British cultural theorist Raymond Williams pointed out (1989), "culture is ordinary". The IASC at issue here is how particular cultural forms dominate.

g) Assumed superiority.

That 'European civilisation' is the pinnacle and other cultures (and hence peoples) are inferior, is deeply ingrained in our education, culture, foreign and domestic policy. The assumption appears savagely in the far right and more subtly elsewhere.

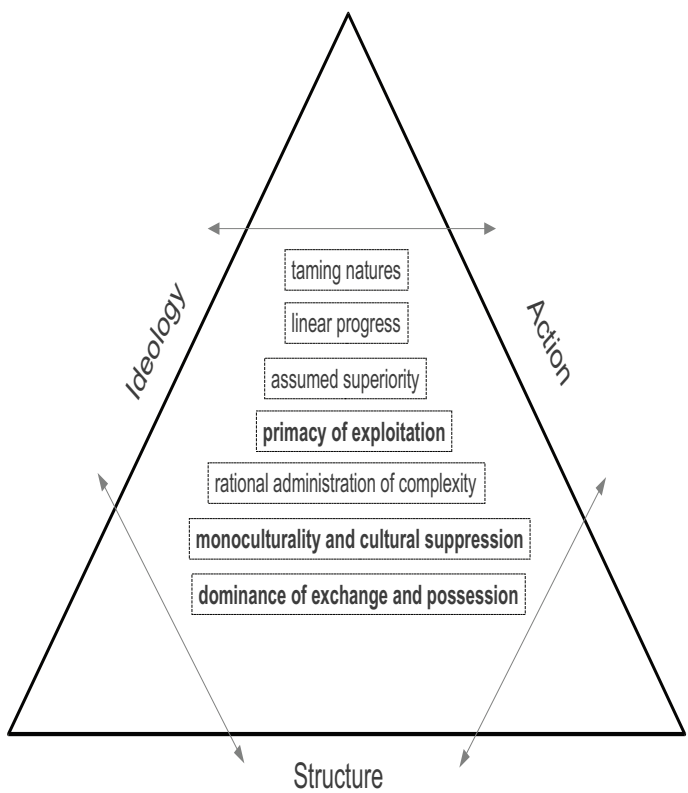

FIGURE 1 - IDEOLOGY-ACTION-STRUCTURE COMPLEXES

Note: As identified by Burton (2013a). Those highlighted in bold font are discussed in this article.

For the purposes of the present article we are particularly interested in three of these complexes: The dominance of exchange and possession, The primacy of exploitation and Mono-culturality and the suppression of other cultural systems. 
These three IASCs work together, systemically, so that the fabric of everyday life becomes dependent on the consumption of commodities (artefacts and services), not just to meet basic needs but to structure interactions and relationships, to construct and display identity and status, to fill free time. The production and exchange of these commodities involves supply chains of global reach with sites of profit accumulation at each step as planetary resources are extracted and squandered and workers are exploited. The saturating totality of this consumerist mode of culture means that escape and the construction of alternatives is extremely difficult. So, for example, when the British government proposed that each school child should have 5 hours per week of cultural activity the rationale was so that they would be prepared to work in the cultural industries (DCMS, 2008): economic rationality (GORZ, 2010) has precedence over any notion of culture for its own sake. Even the subaltern cultural practices of counter-cultures and marginal peoples get transformed into profitable commodities.

The problem that faces critical scholar-activists then, is to find credible points of intervention in this web of domination. The model of IASCs suggests (as does HARVEY, 2010, p. 138-139) that debates over the primacy of one or other mode of domination (economic, political, cultural, environmental, etc.) are likely to be futile and instead there are potentially multiple points for intervention, necessitating a kind of principled opportunism. We identify three possible modes of intervention, from what is likely to be a much larger universe of possibilities. They focus on: a) cultural practices and alternative identity construction; b) place-making or the creation of settings; c) ideological innovation. These interventions are all forms of informal education, building on and extending, through participation, cultural practices, knowledge, understanding and skills. We will illustrate them by way of our own work. In so doing we are not claiming any secret for social transformation, rather we are trying to map and understand some possibilities.

\section{Intervention for cultural growth}

We have already commented on the largely passive and consumerist mode of cultural practice, at least in most of the wealthy 'North' today. A consequence of this is a state whereby for many people, cultural production is not seen as something they can do: there is almost a fear of participation, of failing. People believe they can't draw, act or sing. 
We introduced a singing workshop into the University workplace, in part as a pilot research project into the impact of singing on health and wellbeing and in the alleviation of workplace stress (PURCELL; KAGAN, 2008). Over 20 people from across the University attended the first session. The singing facilitator invited participants to share their reasons for coming to the workshop and at least half of those there said they had always been told they could not sing, although they enjoyed doing so in private. The singing workshops had personal, social and collective impacts. At a personal level people enjoyed the sessions, felt good after them and, for the rest of the day or week, had a strong positive sense of anticipation of the time singing, had strong emotional connection with the music and sometimes the lyrics, and they developed their own skills. At the social level, people met new friends and related differently to those they already knew: the singing workshops facilitated better communications between them and understandings of each other. At a collective level, there were secondary effects of the singing: when participants returned to their offices with uplifted, joyous mood, sometimes humming or singing quietly, the whole atmosphere of their workplaces became lighter and more positive and supportive. One of the workshops was held in an open space in a different building in the University and it was notable that passers by stopped to look, smile, tap their feet and sometimes join in with the songs, demonstrating the readiness of people to engage, even in alien environments. Some participants went on to join choirs or to host singing groups in their homes outside of work. Most tellingly, by the end of the workshops, participants thought of themselves as singers, whereas at the start, only 2 had done so. The singing workshops permitted participants to rediscover their singing voices and reminded them of the positive aspects of singing. Others had had a negative experience of singing and were now able to find the voice they had been told they never had. They enabled people to reconnect with their cultural roots and to rebuild culture in their lives.

\section{The construction of settings}

Successful cultural and community regeneration is often based around a setting. The creation of settings is indeed a key concept in the practice of community psychology (KAGAN et al., 2011, p. 198-207). Settings do not necessarily have to be permanent places, but, as in the above example can be a regular social context for an activity. However, the reclamation of places for collective cultural production is a recurrent feature of political, social and 
cultural resistance. Our city has an impressive history of participative people's culture that was an integral part of the struggles for social justice of the $19^{\text {th }}$ and early $20^{\text {th }}$ centuries. That movement was much more than its trade unions and political parties, instead it was an all embracing social movement with a whole way of life, of social relations that embedded social solidarity, learning, healthy living and cultural enrichment in its choirs, orchestras, meeting halls, schools and institutes, bookshops, cycling and walking clubs and even 'secular churches'. These institutions were not narrowly focussed on life in the city but looked outwards with international solidarity with working people's struggles, an important feature that embodied the values of sharing and caring. Taken together these examples, as a whole way of life, suggest how a new people's culture could emerge again to replace the current culture of passive cultural consumption.

Gardening - growing and nurturing food, flowers, trees - for pleasure and for community enjoyment is a long-standing cultural practice in England (MCKAY, 2011). Many people live in houses with small plots of land attached, or rent small plots of land on marginal land locally. In some areas of multiple deprivation, the gardens have gone or have fallen into disuse. Residents of social housing often live in apartments and the only space they have for recreating this cultural practice is around the edges of the blocks. We worked with some residents of one such area, where social relations were often conflictual and many residents struggled with alcoholism, mental ill health or drug use (STEWART; KAGAN, 2008). Local children had a reputation for being aggressive, sometimes violent and disaffected. Some of the residents wanted to create gardens, retrieving from collective historical memory the skills and knowledge of growing and, at the same time, build community, especially by bringing young and old together. After a lot of work, drawing in local people including some of the children, and getting help from environmental experts from the local council, gardens were created and tended and the community entered and won a regional competition (part of a national competition, known as Britain in Bloom). As the Chair of the local residents' group said: "Local people have surpassed themselves and more people than ever have volunteered, which has brought the community together. We also had a lot more children who did a wonderful job [...] people are really taking a pride in their neighbourhood." Not only did people participate and connect with each other more positively, this only happened as a result of a cultural recuperation project.

People who live lives of marginality, through poverty and mental ill health, in urban areas of England, one of the richest countries of the world, are at risk of becoming separated from others and of the isolation that results from low self esteem and lack of social identity. From our research into the impact of participatory arts on those living with mental health difficulties, we know that 
participation in the arts, in any form, has personal benefits. It also engenders a strong sense of social identity and increased awareness of the other, leading to a growth of social capital and engagement (KILROY et al., 2007; SIXSMITH; KAGAN, 2005). One person, who had learnt to do photography, now considered himself to be a photographer: he still had his problems, but now he was a photographer as well. And he showed great pride in the photographs he had taken that were displayed in the exhibition. Other people in the project grew in self confidence and went on to seek employment. It was not just in the execution of creative activity that the benefits were to be found: the placing of the art in exhibitions or volumes of poetry for wider consumption contributes to cultural enrichment more generally. Central to the transformative experience of arts creation, production and presentation was identity expansion and a greater understanding of the self and the other.

\section{Ideological innovation}

Over the last five years, work has been going on to promote an alternative to the orthodox economic model based on economic growth and competition in a global economy (BURTON, 2009, 2010; BURTON; STEADY STATE MANCHESTER, 2012; CALL TO REAL ACTION, 2009). That model with its assumption that benefits 'trickle down' to the poor has failed to reverse inequality and persistent social deprivation. Moreover, it is impossible to continue with it in a finite world (JACKSON, 2009). It is therefore necessary to outline the characteristics of an alternative approach, supporting and learning from innovations on the ground, and building a coalition in support. To do this requires more than a simple presentation of a 'correct policy framework', but instead requires us to find points of connection with those who, although not necessarily convinced of the radical alternative perspective, have interests in common. For example, local politicians' economic thinking is heavily subject to the assumptions that economic growth is a good thing, yet they are also aware of the need for redistribution, for a more localised economy with shorter and less vulnerable supply chains, and for reform of the financial industry whose uncontrolled manufacture of credit underpins the explosion of consumption (GREEN NEW DEAL GROUP, 2013; PETTIFOR, 2014) and household debt (MONTGOMERIE, 2007; WALKER et al., in submission). Being an ecological-economic activist (DALY; FARLEY, 2011; LATOUCHE, 2010) draws upon social psychological understanding of the processes of influence, identity, 
motivation and the functioning of groups as well as other social science and economic disciplines and implicit craft knowledge of how to do practical politics. From this work it is possible to see a new coalition beginning to emerge, possibly eventually to become a counter-hegemonic bloc (GRAMSCI, 1971), organised around a plural vision of an alternative society that while escaping consumer culture, can offer a better life to its members. However, at this stage the activity is mostly with elite decision makers and influencers, and other activists concerned with social justice and ecological safety: it needs to involve and be influenced by wider sectors, including those with most to gain and lose from leaving the society of consumption (LATOUCHE, 2012b).

The case studies we have reviewed, at their differing levels, and the general problematic within which we have framed them, are all concerned with shifting our societies' way of life to one based on the 'frugal abundance' (LATOUCHE, 2012a) of a non-consumerist, post-growth model of economic, social and ecological well-being. While this has a number of dimensions in the cultural, political and economic spheres, a fundamental underpinning is that socially constituted combination of what is the cognitive, emotional and volitional that we know as 'conscientization'. Indeed, it is difficult to see how any kind of social mobilisation that could change the dominating social and economic reality could occur without a process of conscientization, where people read the world as it is, a fragile set of systems in which we are all embedded, obscured and dominated by the interests of endless capital accumulation. Our understanding of this differs from one that is quite common in many discussions about increasing awareness of ecological issues. In our city, for example, there is a programme of 'carbon literacy' which aims to teach people about the problem of greenhouse gas emissions and climate change, the mechanisms involved and the varying impacts of different activities. In some ways this is worthwhile: particularly among those in positions of influence and power there is uneven understanding of these issues. But this appears similar to what Freire termed 'banking education', a process of providing information to those assumed not to have it. And we know, for example from the history of public health education (JOHNSON, 2012; RAYNER; LANG, 2012), that such approaches are not particularly effective in promoting change at the behavioural level, let alone at the collective political one. Instead, it is necessary to engage people in ways that speak to their own lives, with an implicit offer of improvement, that there can be a better way for us all to live. So the Joy at Work initiative directly engaged people in cultural production, learning with them about a different way of being, repositioning us and them as cultural producers in lieu of cultural consumers. The examples 
we discussed as the creation of settings take the next step in co-constructing environments that provide support for changes in consciousness with a longer term (if not permanent) time frame, directly connecting with people's expressed needs and attempting to meet some of them through the new setting. Finally the approach to 'subaltern policy development' (BURTON, 2013b) in the example on ideological innovation combined the provision of information about the failures of the economic growth model while connecting with stakeholders' interests in social justice as well as their emerging doubts about the hegemonic economic and social discourse - a process that continues with elements that involve ideology, action and structure.

\section{Conclusions}

In this article we have used the notion of ideology-action-structure complexes to consider the relationships between small and medium scale cultural interventions and the big problems facing humanity. This juxtaposition, in terms of scale, may seem a little ridiculous, but it is consistent with the injunction to 'think globally and act locally'. Elsewhere (KAGAN; BURTON, 2000) we have considered how small scale experiments in social change can link up as, or within, larger programmes of social and political change, because the biggest weakness of community level action is its fragmented nature. Our model of 'pre-figurative action research' suggests that important products of the processes of local action and action research are the insights gained into both the possibility of transformative change and the forces opposing it. By integrating the learning from such projects, political programmes can be strengthened. At the same time, through experimenting actively with new social relations, the aims, the 'utopian horizon' of transformative change, can be clarified. Both Gramsci and Williams pointed to the important role of counter-hegemonic organisation and struggle in prefiguring an alternative social model, and using another of Gramsci's concepts, that requires a 'Modern Prince', or from our perspective a 'Transmodern (DUSSEL, 2008) Prince', to coordinate this learning and channel it into political action at the wider societal scale. In our view, and to echo a third concern of Gramsci, the problematic role of intellectuals in that process needs urgent consideration and redefinition. 


\section{REFERENCES}

AFOKO, C.; VOCKINS, D. Framing the economy: the austerity story. London: New Economics Foundation, 2013. Available on line at: <http://www.neweconomics.org/ publications/entry/framing-the-economy-the-austerity-story>. Access: 23/01/2014.

ANDERSON, K.; BOWS, A. Reframing the climate change challenge in light of post2000 emission trends. Philosophical Transactions of the Royal Society A: Mathematical, Physical and Engineering Sciences, v. 366, n. 1882, p. 3863-3882, 13 nov. 2008. Available online at: <http://rsta.royalsocietypublishing.org/cgi/doi/10.1098/rsta.2008.0138>. Access: 25/10/2012.

ASSADOURIAN, E. The rise and fall of consumer cultures. State of the World 2010: Transforming Cultures. Washington DC: Worldwatch Institute, 2010. Available online at: <http://blogs.worldwatch.org/transformingcultures/wp-content/uploads/2009/04/ Chapter-1.pdf $>$. Access: 13/01/2013.

BURTON, M. A Green Deal for the Manchester-Mersey Bioregion: an alternative regional strategy. Manchester, 2009. Available online at: <http://greendealmanchester. files.wordpress.com/2009/08/outline-for-a-green-deal-for-the-manchester-merseybioregion-v-4-4.pdf>.

BURTON, M. Arenewal of ethics. The Psychologist, v. 26, n. 11, p. 802-807, 2013a. Available online at: $<$ http://www.thepsychologist.org.uk/archive/archive_home.cfm/volumeID_26-editionID_232-ArticleID_2364-getfile_getPDF/thepsychologist $\% 5 C 1113$ burt.pdf $>$.

BURTON, M. In and against social policy. Global Journal of Community Psychology Practice, v. 4, n. 2, 2013b. Available online at: <http://www.gjcpp.org/pdfs/burtonv4i2-20130522.pdf>. Access: 14/01/2014.

BURTON, M. The Replacement Economy: How do we get there? Manchester: Green Deal Manchester, 2010. Available online at: <http://www.lulu.com/shop/mark-burton/ the-replacement-economy-how-do-we-get-there/ebook/product-16962821.html>. Access: $21 / 07 / 2014$.

BURTON, M.; STEADY STATE MANCHESTER. In Place of Growth: practical steps to a Manchester where people thrive without harming the planet. Manchester: Steady State Manchester, 2012. v. 1. Available online at: <http://steadystatemanchester.files. wordpress.com/2012/11/ inplaceofgrowth_ipog_-content_final.pdf $>$. (Steady State Manchester Reports). Access: 21/07/2014.

CALL TO REAL ACTION. Call to Real Action, Full Report. Manchester: Manchester Climate Forum, abr. 2009.

DALY, H. E.; FARLEY, J. Ecological economics : principles and applications. Washington, D.C: Island Press, 2011.

DAVIS, M. Planet of slums. London ; New York: Verso, 2007. 
DCMS. Creative Britain: New talents for the New Economy. London: UK Department of Culture, Media and Sport, 2008.

DUSSEL, E. Twenty theses on politics. Durham, North Carolina: Duke University Press, 2008.

GORZ, A. Critique of Economic Reason. London: Verso, 2010.

GRAMSCI, A. Selections from the Prison Notebooks. London: Lawrence and Wishart, 1971.

GREEN NEW DEAL GROUP. A National Plan for the UK: from austerity to the green new deal. [S.1.]: New Weather Institute and Green New Deal Group, 2013. Available online at: <http://www.greennewdealgroup.org/wp-content/uploads/2013/09/Green-New-Deal-5th-Anniversary.pdf $>$. Access: 25/01/2014.

GROSFOGUEL, R. Transmodernity, border thinking, and global coloniality: decolonizing political economy and postcolonial studies. [S.1.]: Eurozine, 2008. Available online at: $<$ http://www.eurozine.com/articles/2008-07-04-grosfoguel-en.html >. Access: $22 / 04 / 2013$.

HARVEY, D. The enigma of capital : and the crises of capitalism. Oxford [England]; New York: Oxford University Press, 2010.

HEINBERG, R. Powerdown : options and actions for a post-carbon world. Forest Row [East Sussex, England]: Clairview, 2004.

JACKSON, T. Prosperity without growth: the transition to a sustainable economy. London: Sustainable Development Commission, 2009. Available online at: $<$ http://www. sd-commission.org.uk/publications/downloads/prosperity_without_growth_report.pdf $>$. Access: 22/08/2012.

JAMES, O. Affluenza. London: Vermilion, 2008.

JOHNSON, S. Communicating sustainability: lessons from public health. Green alliance blog. [S.1: s.n.], 2012. Available online at: <http://greenallianceblog.org.uk/2013/04/02/ communicating-sustainability-lessons-from-public-health/>. Access: 14/02/2014.

KAGAN, C. et al. Critical Community Psychology. Chichester: Wiley, 2011.

KAGAN, C.; BURTON, M. Prefigurative action research: an alternative basis for critical psychology? Annual Review of Critical Psychology, v. 2, p. 73-87, 2000.

KILROY, A. et al. Towards Transformation: Exploring the impact of culture, creativity and the arts on health and wellbeing: a consultation report. Critical $\backslash$ friends, Arts for Health. Manchester: Manchester Metropolitan University, 2007. Available online at: $<$ http://www.compsy.org.uk/Critical\%20friends\%20report $\% 20$ final $\% 20$ amendments. pdf $>$. Access: 14/03/2014.

LANDER, E. Crisis civilizatoria: el tiempo se agota. In: LEÓN, I (Org.). Sumak Kawsay / Buen Vivir y cambios civilizatorios. Quito: FEDAEPS, 2010. p. 27-40. Available online 
at: $<$ http://www.fedaeps.org/IMG/pdf/Sumak_Kawsay_Buen_Vivir_y_cambios_civilizatorios.pdf $>$. Access: 20/01/2013.

LATOUCHE, S. Farewell to Growth. Tradução: David Macey. [S.1.]: Polity Press, 2010.

LATOUCHE, S. La sociedad de la abundancia frugal: Contrasentidos y controversias del decrecimiento. Barcelona: Icaria, 2012a.

LATOUCHE, S. Salir de la sociedad de consumo: voces y vías del decrecimiento. First Spanish edition ed. Barcelona: Ocataedro, 2012b.

MARTINEZ-ALIER, J. Social metabolism, ecological distribution conflicts, and languages of valuation. Capitalism Nature Socialism, v. 20, n. 1, p. 58-87, mar. 2009. Available online at: $<$ http://www.tandfonline.com/doi/abs/10.1080/10455750902727378>. Access: $14 / 08 / 2012$.

MCKAY, G. Radical gardening : politics, idealism \& rebellion in the garden. London: Frances Lincoln Ltd., 2011.

MEADOWS, D. H.; RANDERS, J.; MEADOWS, D. L. Limits to Growth : the 30-Year Update. London: Earthscan, 2005.

MONTGOMERIE, J. Financialization and consumption: an alternative account of rising consumer debt levels in Anglo-America. CRESC Working Paper Series, n. 43. Manchester: Centre for Research on Socio-Cultural Change (CRESC), University of Manchester, 2007. Available online at: $<$ http://www.cresc.ac.uk/sites/default/files/wp43. pdf $>$. Access: 22/08/2012.

PETTIFOR, A. Just Money: How society can break the despotic power of finance. London: Prime Economics, 2014. Available online at: <http://www.primeeconomics. org/?wpsc-product=just-money-how-society-can-break-the-despotic-power-of-finance> .

PURCELL, C.; KAGAN, C. Joy at Work: The Impact of Non-professional singing workshops on employee wellbeing. Research Institute for Health and Social Change report. Manchester: Manchester Metropolitan University, 2008. Available online at: $<$ http://www.compsy.org.uk/Joy\%20at\%20 workevaluation\%20report\%20draft.pdf $>$. Access: 14/03/2014.

RAYNER, G.; LANG, T. Public health and nutrition. Our vision: Where do we go? [Commentary]. World Nutrition, v. 3, n. 4, p. 92-118, abr. 2012. Available online at: $<$ www.wphna.org $>$.

ROCKSTRÖM, J. et al. A safe operating space for humanity. Nature, v. 461, n. 7263, p. 472-475, 2009. Available online at: <http://www.nature.com/doifinder/10.1038/461472a $>$. Access: 24/09/2012. 
SIXSMITH, J.; KAGAN, C. Pathways Project Evaluation. Research Institute for Health and Social Change. Manchester: Manchester Metropolitan University, 2005. Available online at: <http://www.compsy.org.uk/pathways.pdf>. Access: 14/03/2014.

STEWART, A.; KAGAN, C. The “In Bloom” competition: gardening work as a community involvement strategy. Research Institute for Health and Social Change report. Manchester: Manchester Metropolitan University, 2008. Available online at: <http:// www.e-space.mmu.ac.uk/e-space/bitstream/2173/41941/1/978-1-900139-24-3.pdf>. Access: 14/03/2014.

UNITED NATIONS POPULATION FUND (Org.). Population Dynamics in the Post2015 Development Agenda. New York: UN, 2013. Available online at: <https://www. unfpa.org/public/home/publications/pid/16152>. Access: 14/03/2014.

VICTOR, P. A. Growth, degrowth and climate change: A scenario analysis. Ecological Economics, maio 2011. Available online at: <http://degrowth.org/wp-content/uploads/2011/05/Victor_Growth-Degrowth-and-Climate-Change.pdf >. Access: 04/07/2012.

VICTOR, P. A. Managing without growth slower by design, not disaster. Cheltenham; Northampton, Mass.: E. Elgar, 2008.

WALKER, C. et al. Locked into the system? Critical community psychology approaches to personal debt in the context of crises of capital accumulation. In submission.

WILLIAMS, R. Culture is Ordinary. Resources for Hope. London: Verso, 1989.

WILLIAMS, Z. The commercialisation of childhood. London: Compass, 2006. Available online at: < http://www.compassonline.org.uk/wp-content/uploads/2013/05/thecommercialisationofchildhood. pdf $>$. Access: 9/02/2014.

WOODWARD, D. et al. Growth isn't working : the unbalanced distribution of benefits and costs from economic growth. London: New Economics Foundation, 2006. Available online at: <http://www.neweconomics.org/page/-/files/Growth_Isnt_Working.pdf $>$.

Texto recebido em 20 de maio de 2014. Texto aprovado em $1^{\circ}$ de julho de 2014 . 
